\title{
Cost Efficiency Determinants: Evidence from the Canadian Banking Industry
}

\author{
Abayomi Oredegbe ${ }^{1}$ \\ ${ }^{1}$ Department of Business Administration, University College of the North, Manitoba, Canada \\ Correspondence: Abayomi Oredegbe, Department of Business Administration, University College of the North, \\ Manitoba, Canada. E-mail: aoredegbe@ucn.ca
}

Received: November 14, 2019

Accepted: December 5, 2019

Online Published: December 13, 2019

doi:10.5539/ijbm.v15n1p86

URL: https://doi.org/10.5539/ijbm.v15n1p86

\begin{abstract}
This study examines the cost efficiency of the banking industry in Canada. Utilizing 12 years of data (i.e., 2006 to 2017), and a two-stage data envelopment analysis (DEA), it provides insight on the determinants of the industry's cost efficiency. It finds that the industry is cost inefficient, and that it could reduce costs by 11.52 percent. The cost inefficiency is due to technical and allocative inefficiencies, with technical inefficiency playing a dominant role. The technical efficiency decomposition shows that pure technical efficiency improved, but the scale efficiency deteriorated. The analysis of the determinants of cost efficiency reveals that deposit conversion into loans, high capitalization, and managerial tolerance for increase in administrative expense drive cost efficiency. On the other hand, market power and diversification diminish cost efficiency. In addition, the impact of profitability and credit risk are inconsequential to cost efficiency. This study contributes to literature by providing insights unique to Canada. Managers in the industry, policy makers, and regulators can point to these findings as empirical evidence supporting measures aimed at increasing the industry's competitiveness and resilience.
\end{abstract}

Keywords: Canadian banking, cost efficiency, data envelopment analysis (DEA), Tobit Model

\section{Introduction}

The banking industry plays an important role in the economy, creating liquidity, and facilitating the movement of funds from depositors to borrowers (Ouenniche \& Carrales, 2018). The Federal Bank Act guides the industry in Canada. To ensure that the Act is current, the "sunset clause" requires periodic review and update (Forgione, Mirza, Ammerman, \& Armstrong, 2017, p. 19). In 2017, the industry accounted for 3.3 percent of Canada's gross domestic product (GDP) and employed about 276,000 people (Canadian Bankers Association, 2019). The Office of Superintendent of the Financial Institutions in Canada (OSFI), and the Financial Consumer Agency of Canada (FCAC) regulate the industry. OSFI oversees and regulates financial institutions (i.e., banks, insurance, and trust and loan companies), whereas FCAC protects customers by ensuring that banks comply with market conduct requirements (FCAC, 2016). In addition to the roles of OSFI and FCAC, the Bank of Canada (BOC) and the Canadian Deposit Insurance Corporation (CDIC) monitor the industry for stability. While the BOC makes liquidity available to banks and ensures functional payment and settlement clearing systems, the CDIC insures deposits held in federally regulated banks and financial institutions (Department of Finance Canada, 2016). The presence of credit unions, near banks, and virtual banks makes the industry look competitive. However, the industry is dominated by six banks (i.e., Bank of Montreal, BOM; Canadian Imperial Bank of Commerce, CIBC; National Bank of Canada; Royal Bank of Canada, RBC; The Bank of Nova Scotia; Toronto Dominion Bank, TD) holding more than 90 percent of the industry's assets (Department of Finance Canada, 2016). Because the banking industry is integral to the overall economy (Cooray, 2009), it is important for it to convert inputs into outputs at minimum costs. Given that efficiency centres on how inputs are used to generate outputs (Coeli et al., 2005), a cost efficient banking industry will produce better outcomes, converting inputs to outputs at minimum costs than an inefficient one (Spulbar, Nitoi, \& Anghel, 2015). In essence, cost efficiency indicates how well the industry is minimizing costs (Aboagye, 2012). High cost efficiency signals better control of costs, reducing the risk of vulnerability or exposure to failure (Hassan \& Jreisat, 2016). Despite withstanding the 2008 financial crisis, the threat of global economic uncertainties, competition, technological advancement, new regulatory framework, and changing needs of customers are generating concerns about the industry's competitive position, 
stability, and exposure to vulnerability (Bank of Canada, 2019; IBISWorld, 2019). It is important to investigate the cost efficiency of the industry and factors that influence it because most studies on Canada (e.g., Ghaeli, 2019; Howland \& Rowse, 2006) focus on the technical efficiency and shed light on how inputs are used to generate outputs. The meagre number of studies on the cost efficiency of the industry are inadequate. Ruinan (2019) compared the cost efficiency values between Canada and US using stochastic frontier analysis (SFA) and data envelopment analysis (DEA). Another study (i.e., Xiang, Shamsuddin, \& Worthington, 2015) adopted SFA and compared Canada with Australia, and the UK. Although it reported on the cost efficiency of the industry from 1998 to 2008 and discussed the factors that explain the differences in efficiencies of the three countries, not covering periods after the 2008 financial crisis limits its relevance. In addition, unlike DEA, the SFA approach, which requires that production function be specified could generate biased efficiency estimates if the wrong production function is chosen (Coeli et al., 2005). This recognition prompts the focus of this study. Using DEA addresses the concern about model misspecification. Additionally, incorporating data from periods prior to and after 2008 satisfies the need for an empirical research that reflects current banking operating conditions in Canada. Using data from 2006 to 2017 in the investigation of the cost efficiency of the industry and factors that influence it provides stakeholders within and outside the industry better understanding of the industry. As a result, managers in the industry are better equipped to predict costs and adapt strategies in order to meet cost efficiency targets. In addition, to position the industry on a more sustainable path, regulators and policy makers may use this study as empirical evidence during policy discussion and formulation. By focusing on Canada, this study contributes to banking industry efficiency discuss as it addresses the inadequacy of literature reflecting Canadian context. The next section outlines the review of related studies. Section 3 presents the methodology and data. Section 4 discusses the results. Section 5 concludes with a highlight of the implications of the study and suggestions for future research.

\section{Review of Literature}

Studies (e.g., Kumar, 2013; Balasubramanyan, Stefanou, \& Stokes, 2010) that have investigated the banking industry express that cost inefficiency signals poor performance. Given the importance of the industry's stability to the overall economy (Daude \& Pascal, 2017; Gunes \& Yildirim, 2016), iota of concerns has economic implications that could agitate depositors and investors, emboldening regulators and policy makers to intervene in the affairs of the industry. Interestingly, studies have examined banking industry efficiency through the lens of technical efficiency (e.g., Horvatova, 2018; Saha, Ahmad, \& Dash, 2015; Moradi-Motlagh \& Saleh, 2014; Banker, Chang \& Lee, 2010; Casu \& Giradone, 2006), and cost and allocative efficiencies (e.g., Kasman \& Carvallo, 2013; Akeem \& Moses, 2014; Kumar, 2013; Feng \& Serletis, 2009; Hartman, Storbeck, Byrnes, 2001). In addition, the industry has been examined in single country studies (e.g., Ding \& Sickles, 2018; Hassan \& Jreisat, 2016, Vu \& Turnell, 2011), cross-country studies (e.g., Rekik \& Kalai, 2018; Banerjee, 2013; Kasman \& Carvallo, 2013), and under approaches that include ratio analysis (e.g., Klaassen, \& van Eeghen, 2015; Kumbirai \& Webb, 2010) and frontier analysis (e.g.,Moradi-Motlagh, Valadkhani, \& Saleh, 2015; Weill, 2004; Berger \& Humphrey, 1997). Typically, ratio analysis studies assess profitability, liquidity, solvency, and leverage ratios, declaring improvements in these ratios over time as indicative of good performance (Kumbirai \& Webb, 2010). However, as noted in Paradi, Min, \& Yang (2015) and Berger, Hunter \& Trimme (1993), the ratio approach is simple to use, but it can be misleading when applied to multi-input and multi-output banking industry as it does not reflect all of the inputs used to generate outputs. In addition, the ratio approach ignores interactions between the multiple inputs and outputs, hampering its predictive ability (Serebrisky, 2012). These deficiencies are rationales for using the frontier approach in several banking industry studies including Mousa (2015) and Paradi, Min, \& Yang (2015). Unlike the ratio approach, frontier analysis can accommodate multiple inputs and outputs (Sharma, Sharma, \& Barua, 2013). A frontier approach commonly used in banking efficiency study is stochastic frontier analysis (SFA), which is a parametric approach with statistical testing capability, however it requires that the production function be specified (Coeli et. al., 2005). Another frontier approach that studies rely on is data envelopment analysis (DEA), which is a nonparametric approach that is sensitive to measurement error, but it does not require that the production function be specified (Coeli et al., 2005). The findings in single country SFA (e.g., Gunes \& Yildirim, 2016; Stanek, 2015; Rouissi \& Bouzgarrou, 2012; Vu \& Turnell, 2011; Kalluru \& Bhat, 2009) and DEA (e.g., Batir, Volkman, \& Gungor, 2017; Hassan \& Jreisat, 2016; Kocisova, 2014; Kumar, 2013; Daley, Matthews \& Zhang, 2013) studies reveal cost inefficiency. However, while some of these studies (e.g., Batir, Volkman, \& Gungor, 2017; Gunes \& Yildirim, 2016; Daley, Mathews \& Zhang, 2013) present evidence that show improvement in cost efficiency over time, others (e.g., Hassan \& Jreisat, 2016; Feng \& Serletis, 2009; Kalluru \& Bhat, 2009) point to deterioration. Similarly, cross-country SFA (e.g., Rekik \& Kalai, 2018; Spulbar \& Nitoi, 2014; Perera, Skully, \& Wickramanayake, 2007) and DEA (e.g., Belas, Kocisova, \& Gavurova, 2019; Banya \& Biekpe, 2018; Kacisova, 2014; Casu and Giradone, 2006) studies indicate cost inefficiency and 
variations among the sample of countries examined. As studies differ on findings, there is shift in focus from assessing the cost efficiency and trends over time to understanding the factors that influence it. Generally, studies vary on the choice of variables investigated, nonetheless, they provide insights on the influence of three broad categories of variables, including bank specific variables (e.g., profitability, bank ownership, bank size, bank equity, bank risk, liquidity risk, and financial leverage), industry specific variables (e.g., industry concentration, market structure, and competition), and macroeconomic variables (e.g., GDP, economic growth, and inflation). In some studies (e.g., Hassan \& Jreisat, 2016; Stanek, 2015), the evaluation entails finding the link between efficiency and variables from a single category. In other studies (e.g., Belas, Kocisova, \& Gavurova, 2019; Rahman, Ashraf, Zheng, \& Begum, 2017), the examination involves variables from more than one category. Regarding studies on the Canadian banking industry, most focus on technical efficiency (e.g., Paradi, Min, \& Yang, 2015; Allen and Engert, 2007), and comparison with a handful of countries (e.g., Ghaeli, 2019; Xiang, Shamsuddin, \& Worthington, 2015). In addition, a few (e.g., Asmild, Paradi, Aggarwall, \& Schaffnit, 2004; Parsons, Gotlieb, \& Denny, 1993) examined the industry's productivity. Ruinan (2019) and Xiang, Shamsuddin, \& Worthington (2015) are studies on the cost efficiency of the industry. Unlike Ruinan (2019), Xiang, Shamsuddin, \& Worthington (2015) looked at factors responsible for differences in the cost efficiency of the countries studied, however, its relevance is limited because the period of focus (i.e. 1998 to 2008) may not reflect current banking operating environment. Additionally, SFA typically reports bias efficiency estimates if the functional form of the model used is inappropriate (Coeli et al., 2005). In general, studies find cost inefficiency in the Canadian banking industry, or suggest that the cost efficiency in the industry lags behind those of other countries. Since evidence reflecting current banking operating conditions is limited, the empirical evidence in this study satisfies the need for adequate understanding of the Canadian situation given current operating environment. In addition, uncovering the factors that drive cost efficiency contributes to the burgeoning discuss relating to the industry's competitiveness and resilience.

\section{Methodology and Data}

This study uses a two-stage DEA. In the first stage, the cost efficiency of the industry and the associated allocative and technical efficiencies were assessed using DEA. The DEA introduced in Charnes, Cooper, \& Rhodes (1978) is a linear programming technique involving the construction of piecewise frontier (Coeli et al., 2005). As a nonparametric approach, it measures the efficiency of the industry in each year relative to the best frontier (Casu \& Girardone, 2006). DEA can be input, or output oriented (Cooper, Seiford, \& Tone, 2007). In an input oriented DEA, the objective is to minimize inputs for a given level of outputs. On the other hand, in an output oriented DEA, the aim is to determine the amount by which outputs could be increased without additional inputs (Cooper, Seiford, \& Tone, 2007). As noted in Coeli et al. (2005), the choice between input and output oriented DEA is determined by the variables that the decision maker has control over. Since managers in the banking industry have control over inputs than they do over outputs, this study adopts the input oriented DEA. In addition, the industry's output is influenced by factors such as regulation, competition, and economic conditions that managers have no control over, making the input oriented model appropriate. Similar to Batir, Volkman \& Gungor (2017) and Kumar (2013), the cost efficiency was assessed with constant return to scale (CRS) imposed in the DEA model. Also, components of cost efficiency (i.e., allocative efficiency, AE; technical efficiency, TE) were evaluated. The supposition under CRS is that the industry operates at optimal scale (Coeli et al., 2005). Unlike the variable return to scale (VRS) which compares each decision making unit (DMU) to those of similar sizes, the CRS compares all of the DMUs irrespective of size (Kumar, 2013). The technical efficiency estimates under CRS were decomposed into pure technical efficiency (PTE) and scale efficiency (SE). The PTE is the technical efficiency without scale impact (Banker, Cooper, Seiford, Thrall, \& Zhu, 2004), providing information on the effectiveness of managers in converting inputs to outputs (Kumar \& Gulati, 2008). The extracted SE yields information on the appropriateness of the industry's operational scale size (Kumar \& Gulati, 2008).

In the second stage, Tobit model was used to regress the cost efficiency scores against environmental variables. The Tobit model is appropriate because DEA efficiency scores resemble corner solution variable with values typically between zero (0) and one (1) (Hoff, 2007). Some studies that have used Tobit model to regress DEA efficiency scores against environmental variables include Batir, Volkman, \& Gungor (2017), Chan, Zaini, \& Karim (2016), Saha, Ahmad, \& Dash (2015), Rosman, Wahab, \& Zainol (2014), and Ab-Rahim, Md-Nor, Ramlee, \& Ubaidillah (2012). Approaches on which studies base input and output selections are production, intermediation, value added, asset, and operating (Sharma, Sharma, \& Barua, 2013), however, the production and intermediation approaches are widely used (Banya \& Biekpe, 2018; Sharma, Sharma, \& Barua, 2013; Kosedag, Denizel, \& Ozdemir, 2011). The production approach views banks as using labour and capital in the process of providing services to customers, thus, it considers deposits and the number of accounts or loan 
transactions as outputs (Tripe, 2003; Berger \& Humphrey, 1997). The intermediation approach sees banks as performing intermediation function, including facilitating the conversion of deposits from savers into loans (Sharma, Sharma, \& Barua, 2013). It incorporates operating and interest expenses, deposits, labour, and capital as inputs, whereas loans and other major assets as regarded as outputs (Maredza, 2014; Kamau, 2011). This research uses three inputs and two outputs in the DEA, and adopts the intermediation approach because banks transform deposits into loans and investments. In addition, the intermediation approach is appropriate when evaluating the industry (Batir, Volkman, \& Gungor, 2017; Berger \& Humphrey, 1997). The three inputs are deposits, employment, and non-interest expense, and the two outputs are loans and net-interest income. Data on the inputs and outputs are from the Conference Board of Canada report, Canadian Bankers Association database, and the annual financial reports of the banks involved in the study. Similar to the approach in Allen and Engert (2007), variables in Canadian dollars are corrected for inflation using CPI with 2015 as the base year.

\section{Results and Discussion}

\subsection{Cost Efficiency}

Table 1 presents the mean efficiency scores in each year. The mean cost efficiency is 0.8848 , indicating that the industry is cost inefficient by 11.52 percent in unwarranted costs. This finding aligns with Allen and Engert (2007) depiction of the industry as cost inefficient. The dispersion of the efficiency measures as indicated by the coefficient of variation (CV) (Table 1) shows the industry's cost efficiency is more dispersed than the other efficiency measures. In addition, the deterioration in cost efficiency from 0.8996 in 2006 to 0.8543 in 2017 (Figure 1) suggests that banks in the industry are losing control of costs, thereby increasing their vulnerability. Allocative efficiency (AE) is 0.9686 (Table 1), signifying 3.14 percent allocative inefficiency in the industry. The industry's AE trends in Figure 1 show a decline from 0.9738 in 2006 to 0.9581 in 2017, indicating that banks in the industry have difficulty identifying the right combination of inputs for costs to be minimized, given the price of inputs (Isik \& Hassan, 2002). Because banks in the industry are misallocating resources or using resources in wrong combinations, they could train or reassign employees and review lending policies to improve resource allocation. The mean technical efficiency is 0.9130 (Table 1), signifying technical inefficiency in the industry. It shows that banks in the industry are wasting resources; they could reduce inputs by 8.7 percent without affecting output. The situation worsened in that the technical efficiency declined from 0.9240 in 2006 to 0.8911 in 2017 (Figure 1). The technical inefficiency finding is consistent with Ghaeli (2019) and Xiang, Shamsuddin \& Worthington (2015) portrayal of the industry. Given that cost efficiency is the product of allocative efficiency (AE) and technical efficiency (TE), the AE and TE findings imply that the industry's cost inefficiency is largely due to technical inefficiency. Decomposing the technical efficiency (TE) into pure technical efficiency (PTE) and scale efficiency (SE) provides information on the effectiveness of managers and the operational scale of banks in the industry (Kumar \& Gulati, 2008). The mean PTE of 0.9894 (Table 1) denotes a high level of managerial resourcefulness. Improvement in PTE from 0.9873 in 2006 to 0.9981 in 2017 (Figure 2) points to enhanced managerial performance. Nonetheless, the existence of 1.06 percent pure technical inefficiency implies that there is opportunity to improve PTE. Hiring competent managers, providing training, and offering rewards or incentives could motivate managers to use resources skillfully. The mean scale efficiency of 0.9226 (Table 1) signals 7.74 percent scale inefficiency in the industry. This finding is consistent with Allen \& Liu (2007) study that shows the industry as scale inefficient. The industry's scale inefficiency exacerbated, declining from 0.9360 in 2006 to 0.8927 in 2017 (Figure 2). This suggests that banks in the industry have not taken the right measures to adjust operational scale to the most productive size. In addition, the finding that PTE improved while SE declined shows that inefficient operational scale of banks accounts for most of the technical inefficiency in the industry. 
Table 1. Mean efficiency scores

\begin{tabular}{|c|c|c|c|c|c|}
\hline \multicolumn{6}{|c|}{ Constant Return to Scale (CRS) } \\
\hline & $\begin{array}{l}\text { Cost Efficiency } \\
\text { (CE) }\end{array}$ & $\begin{array}{l}\text { Allocative } \\
\text { Efficiency (AE) }\end{array}$ & $\begin{array}{l}\text { Technical } \\
\text { Efficiency (TE) }\end{array}$ & $\begin{array}{l}\text { Pure Technical } \\
\text { Efficiency (PTE) }\end{array}$ & $\begin{array}{l}\text { Scale Efficiency } \\
\text { (SE) }\end{array}$ \\
\hline 2006 & 0.8996 & 0.9738 & 0.9240 & 0.9873 & 0.9360 \\
\hline 2007 & 0.8816 & 0.9830 & 0.8965 & 0.9793 & 0.9152 \\
\hline 2008 & 0.9289 & 0.9535 & 0.9741 & 0.9989 & 0.9752 \\
\hline 2009 & 0.9462 & 0.9778 & 0.9676 & 0.9893 & 0.9781 \\
\hline 2010 & 0.8680 & 0.9710 & 0.8935 & 0.9760 & 0.9160 \\
\hline 2011 & 0.8475 & 0.9778 & 0.8663 & 0.9891 & 0.8756 \\
\hline 2012 & 0.9003 & 0.9839 & 0.9144 & 0.9932 & 0.9208 \\
\hline 2013 & 0.9070 & 0.9823 & 0.9231 & 0.9939 & 0.9288 \\
\hline 2014 & 0.9398 & 0.9826 & 0.9557 & 0.9896 & 0.9654 \\
\hline 2015 & 0.8813 & 0.9754 & 0.9028 & 0.9899 & 0.9117 \\
\hline 2016 & 0.7634 & 0.9037 & 0.8464 & 0.9885 & 0.8554 \\
\hline 2017 & 0.8543 & 0.9581 & 0.8911 & 0.9981 & 0.8927 \\
\hline Mean & 0.8848 & 0.9686 & 0.9130 & 0.9894 & 0.9226 \\
\hline Median & 0.8906 & 0.9766 & 0.9086 & 0.9894 & 0.9184 \\
\hline Stan. Dev. & 0.0496 & 0.0226 & 0.0389 & 0.0067 & 0.0378 \\
\hline Minimum & 0.7634 & 0.9037 & 0.8464 & 0.9760 & 0.8554 \\
\hline Maximum & 0.9462 & 0.9838 & 0.9741 & 0.9989 & 0.9781 \\
\hline CV $(\%)$ & 5.61 & 2.33 & 4.26 & 0.68 & 4.10 \\
\hline
\end{tabular}

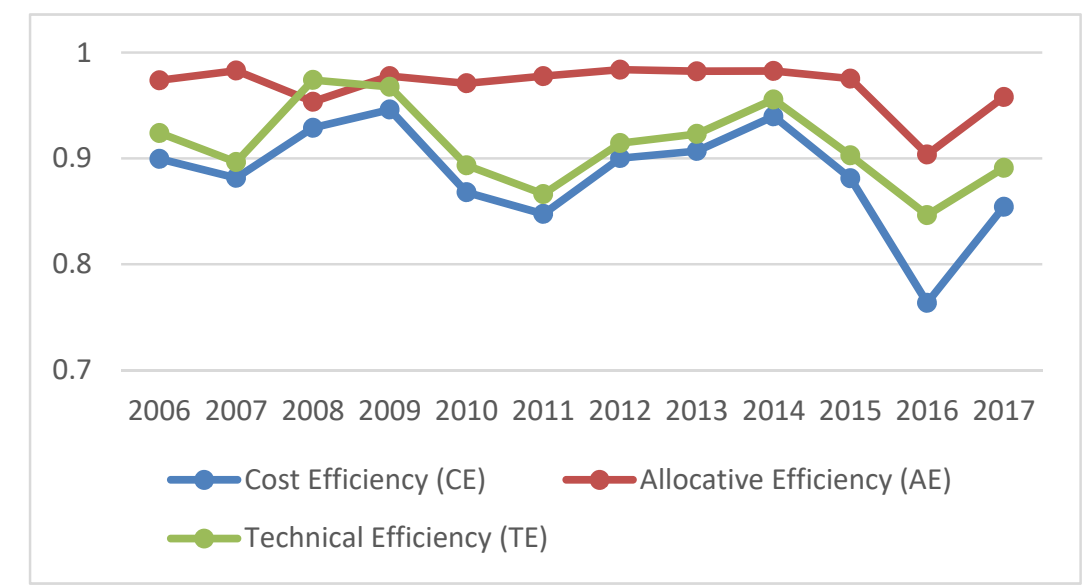

Figure 1. Cost Efficiency (CE), Allocative Efficiency (AE), and Technical Efficiency (TE) trends 


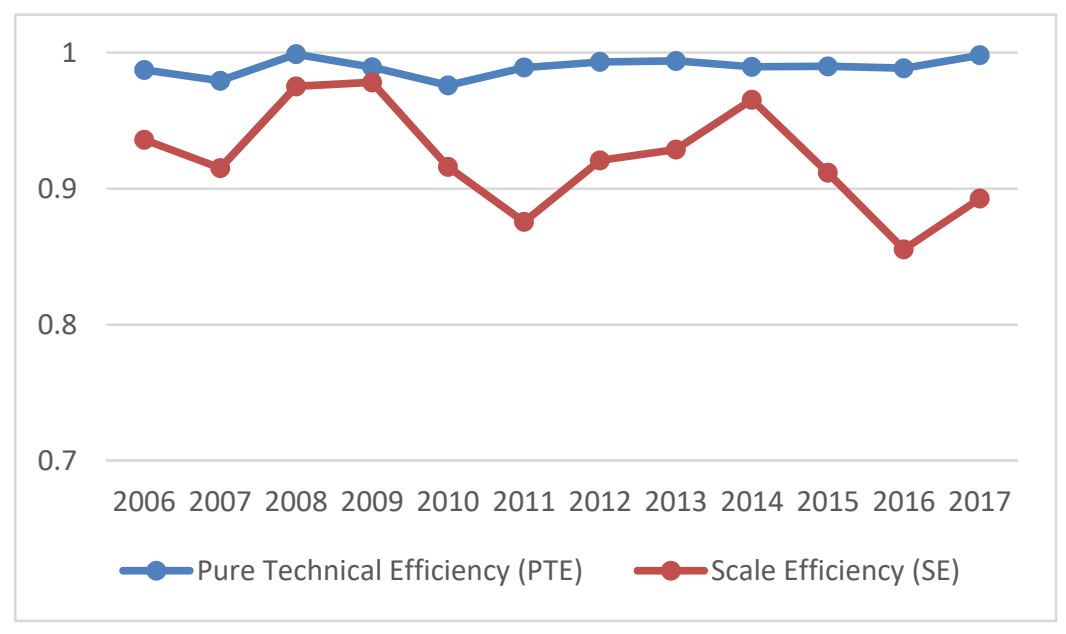

Figure 2. Pure Technical Efficiency (PTE) and Scale Efficiency (SE) trends

\subsection{Determinants of Cost Efficiency}

The Tobit model for estimating the influence of environmental variables is:

$$
\begin{gathered}
C E_{i t}=\beta_{0}+\beta_{1} \text { MKTSH }_{i t}+\beta_{2} \text { LLPTL }_{i t}+\beta_{3} \text { LOTD }_{i t}+\beta_{4} \text { NIETA }_{i t}+\beta_{5} \text { NIITA }_{i t}+\beta_{6} E_{7} \text { ETA }_{i t}+ \\
\beta_{7} \text { ROE }_{i t}+u_{i t}
\end{gathered}
$$

Table 2 provides the Tobit model results at 95 percent confidence level. Market share (MKTSH) variable as the proxy for market power (Gunes \& Yilmaz, 2016) elucidates the influence of market power on cost efficiency. It shows a statistically significant negative relationship with cost efficiency, implying that cost efficiency declines as banks acquire market power. This finding contradicts Perera, Skully \& Wickramanayake (2007) suggestion that large banks penetrate market, and increase revenues at relatively low costs. Nonetheless, the finding that market power undermines cost efficiency augments Berger and Hannan (1998) study that indicates that banks in concentrated markets tend to show diminished cost efficiency. A plausible explanation is that with enlarged market share, banks increase in size and operate outside their most productive operational scale size, incurring excessive costs as a result (Ab-Rahim, Md-Nor, Ramlee, \& Ubaidillah, 2012). In addition, the bureaucracy in large banks with market power could impede response to market conditions (Margaritis \& Psillaki, 2007), resulting in cost inefficiency. Also, a bank could incur higher costs if it resorts to offering better rates to depositors and loan seekers, or if it commits more resources to lobbying the government to protect or increase its market power (Berger \& Hannan, 1998). The ratio of loan loss provision to total loan (LLPTL) reflects credit risk associated with loans (Lall, 2014; Lee \& Chi, 2013). It exhibits negative but statistically insignificant effect on cost efficiency, signifying that increasing credit risk has inconsequential effect on cost efficiency. This finding aligns with (Ab-Rahim et. el., 2012) but contradicts Aiello \& Bonanno (2013). Although the proxy for credit risk is not relevant to cost efficiency, it will be prudent for banks to pay attention to it to avoid plausible negative impact on cost efficiency (Xiang, Shamsuddin, \& Worthington, 2015). Loan loss provisions are set aside to cover delinquent loans and losses relating to loans (Cummings \& Durrani, 2016), allowing banks to absorb loan defaults. However, it may reflect poor credit management by banks if inadequate vetting of loan applicants or poorly negotiated loan terms cause costs to rise. Nonetheless, the credit risk that LLPTL represents is not relevant to cost efficiency as banks may also use high loan loss provisions to achieve earnings and tax objectives (Cummings \& Durrani, 2016; Skala, 2015). Loan to total deposit (LOTD) as a measure of liquidity risk provides insight on the influence of deposit conversion into loans (Rouissi \& Bouzgarrou, 2012; Vu \& Turnell, 2011). High LOTD indicates low liquidity, increasing vulnerability and exposure to failure from loan defaults, or unexpected increase in withdrawals (Amin, Ali, \& Nor, 2018). It exercises statistically significant positive influence on cost efficiency, signifying that banks that convert high percentage of deposits into loans boost cost efficiency. This finding diverges from Lin (2005) suggestion that increasing LOTD undermines cost efficiency. However, the finding corroborates Amin, Ali, and Nor (2018) observation that despite low liquidity position, cost reduction moves banks to finance loans. The finding is also consistent with Xiang, Shamsuddin, \& Worthington (2015) finding that converting deposits into loans increase cost efficiency. It is also comparable to Gunes \& Yildirim (2016) and Daude \& Pascal (2017) outlook that increasing loan to deposit ratio improves cost efficiency. Non-interest expense to total assets (NIETA) variable depicts the influence of administrative expense (Vu \& 
Turnell, 2011), providing insights on how expense control by management affects cost efficiency. It exerts a positive and statistically significant effect on cost efficiency, implying that tolerance for increased administrative expense improves cost efficiency. This contradicts Hassan and Jreisat (2016) suggestion that NIETA diminishes cost efficiency. Nonetheless, the finding that tolerance for increased administrative expense improves cost efficiency is consistent with Batir, Volkman, and Gungor (2017) study showing a positive link between NIETA and cost efficiency. Non-interest expense could reflect spending on salaries and benefits, compliance with regulation, expenditures on equipment and property, and loan monitoring and management (Samad, 2014). A bank tolerant of these expenses will boost cost efficiency because it will be in a suitable position to attract deposits, make better quality loans, and reduce the risk of loan defaults. Non-interest income to total assets (NIITA) variable captures the influence of diversification and business mix (Saha, Ahmad, \& Dash, 2015; Casu \& Giradone, 2006). Although banks diversify to mitigate risk (Kasman \& Carvallo, 2013), the diversification variable has a statistically significant negative relationship with cost efficiency, suggesting that cost efficiency deteriorates with increased diversification. The negative impact of diversification on cost efficiency could be due to scale diseconomies as resources are expended on different business mix (Fiordelisi, Marques-Ibanez, \& Molyneux, 2010). This finding buttresses Aiello and Bonnano (2016) and Spulbar and Nitoi (2014) notations that banks efforts at diversifying diminish cost efficiency. The ratio of equity to total assets (EQTA) reflects capitalization (Lall, 2014; Vu \& Turnell, 2011). It has a positive and statistically significant relationship with cost efficiency, signifying that well capitalized banks have better cost efficiency. While this finding contradicts Rouissi \& Bouzgarrou (2012) suggestion that capitalization diminishes cost efficiency, it is in line with Belas, Kocisova, \& Gavurova (2019) study that shows that well capitalized banks have low leverage, face low risk of vulnerability, and are able to attract funds at low costs, enhancing cost efficiency as a result. Return on equity (ROE) variable is a measure of profitability (Bucevska \& Misheva, 2017). It has a statistically insignificant positive influence on cost efficiency, indicating that higher profitability could drive cost efficiency, but the influence is immaterial. This finding is consistent with Olson \& Zoubi (2011) report of no significant link between cost efficiency and profitability. The finding of positive relationship is similar to Hassan \& Jreisat (2016), however, unlike Hassan \& Jreisat (2016) that suggests that the relationship is significant, this study shows that it is statistically insignificant.

Table 2. Tobit model output

\begin{tabular}{|c|c|c|c|c|c|c|}
\hline \multicolumn{7}{|c|}{ Number of obs $=96$} \\
\hline \multicolumn{7}{|c|}{$\operatorname{LR} \operatorname{chi} 2(7)=60.18$} \\
\hline \multicolumn{7}{|c|}{ Prob $>$ chi $2=0.0000$} \\
\hline \multicolumn{7}{|c|}{ Log likelihood $=73.843525$} \\
\hline \multicolumn{7}{|c|}{ Pseudo R2 $=-0.6877$} \\
\hline $\mathbf{C E}$ & Coef. & Std. Err. & $\mathbf{t}$ & $\mathbf{p}>/ \mathbf{t} /$ & \multicolumn{2}{|c|}{ [95\% Conf. Interval] } \\
\hline MKTSH & -0.0038326 & 0.0012967 & -2.96 & 0.004 & -0.0064092 & -0.0012559 \\
\hline LLPTL & -0.0297151 & 0.0230533 & -1.29 & 0.201 & -0.0755216 & 0.0160914 \\
\hline LOTD & 0.0017252 & 0.000785 & 2.20 & 0.031 & 0.0001655 & 0.0032849 \\
\hline NIETA & 0.1398589 & 0.0413572 & 3.38 & 0.001 & 0.0576831 & 0.2220347 \\
\hline NIITA & -0.0924278 & 0.0334715 & -2.76 & 0.007 & -0.158935 & -0.0259206 \\
\hline EQTA & 0.027376 & 0.0085756 & 3.19 & 0.002 & 0.0103365 & 0.0444155 \\
\hline ROE & 0.0027022 & 0.0023032 & 1.17 & 0.244 & -0.0018742 & 0.0072786 \\
\hline Cons & 0.4622166 & 0.1226002 & 3.77 & 0.000 & 0.2185968 & 0.7058364 \\
\hline /Sigma & 0.0797509 & 0.0066188 & & & 0.0665994 & 0.0929023 \\
\hline \multicolumn{7}{|c|}{0 Left-censored observations } \\
\hline \multicolumn{7}{|c|}{77 uncensored observation } \\
\hline \multicolumn{7}{|c|}{19 right-censored observations at $\mathrm{CE}>=1$} \\
\hline
\end{tabular}

Note. $\mathrm{CE}=$ Cost Efficiency.

\section{Conclusion}

This study examines the determinants of cost efficiency in the Canadian banking industry. To achieve this, it utilized a two-stage DEA. Similar to prior study (e.g., Ruinan, 2019; Xiang, Shamsuddin, \& Worthington, 2015), this study shows that the industry is cost inefficient. Banks in the industry could have produced current outputs with just 88.48 percent of the costs incurred. In other words, banks in the industry could eliminate 11.52 percent 
of the current costs. Because the cost inefficiency is due to technical and allocative inefficiencies, it is apparent that banks in the industry are wasting resources and are incorrectly combining inputs. However, based on the finding that technical inefficiency accounts for a greater proportion of the cost inefficiency, interventions should prioritize addressing the technical inefficiency. Furthermore, given that technical efficiency is dictated by managerial effectiveness and operational scale (Kumar \& Gulati, 2008), the finding that pure technical efficiency improved while scale efficiency deteriorated highlights the precarious nature of the suboptimal operating scale of banks in the industry. Scale adjustment is necessary for technical efficiency to get better. In addition, the observed improvement in PTE can the sustained by promoting managerial effectiveness through better training and reward systems for managers to be resourceful. Findings relating to the influence of environmental variables on cost efficiency provide important insights. The significant negative impact of market share implies that cost efficiency declines as banks accumulate market power. Enlarged market share requires coordination and monitoring, increasing cost for banks. In addition, diseconomies of scale may occur as enlarged market share could push banks to increase beyond their ideal operational scale size (Ding \& Sickles, 2018). In view of this, it is important that regulators promote competition in the industry. With the finding that LOTD improves cost efficiency, banks could be tempted to finance loans while exposed to liquidity risk (Lee \& Chi, 2013). Typically, banks address liquidity issues by using high cost non-deposits and by liquidating assets, but risk long-term viability doing so (Lall, 2014). To ensure liquidity of banks, regulators need to monitor banks for compliance with liquidity and lending requirements. While the conversion of deposits into loans enhance cost efficiency, the exposure to credit risk would require more provisions for losses, exerting negative but immaterial effect on cost efficiency. Nonetheless, to reduce exposure to credit risk, banks need to properly screen loan applicants and avoid aggressive lending practices. In addition, regulators should ensure that banks adhere to statutory lending requirements and make adequate provisions to cover incidence of loan defaults. Tolerance for increased administrative expense improves cost efficiency. Since it reflects spending on compliance with regulation, expenditures on equipment and property, and loan monitoring and management (Samad, 2014), a bank tolerant of this expense could realize good reputation from it, attract deposits, and process and approve loans to customers with low risk of default. This study also shows that cost efficiency in banks with high degree of diversification will lag behind their counterparts with no or low levels of diversification. The general notion is that banks diversify to reduce risk and to improve profits (Saha, Ahmad, \& Dash, 2015; Kasman \& Carvallo, 2013), however this study reveals that diversification does not improve cost efficiency. For banks that diversify, the associated cost could be too high, and may neutralize the benefits of the diversification (Stiroh \& Rumble, 2006), hindering cost efficiency in the process. This finding highlights the need for banks to focus on traditional banking services (i.e., intermediation). By concentrating on intermediation services, banks become specialized and could attain the economies of scale needed to produce and offer products and services at minimum costs (Fiordelisi, Marques-Ibanez, \& Molyneux, 2010; Casu \& Giradone, 2006). With the revelation that capitalization boosts cost efficiency, regulators need to ensure that banks are well capitalized. This will reduce vulnerability and risk of failure, making it possible for banks to attract funds at low costs (Belas, Kocisova, \& Gavurova, 2019). Additionally, this study finds that profitability is not a relevant predictor of cost efficiency. Nonetheless, it is possible that performance metrics based on profitability will motivate managers in the industry to focus on revenue generation than on cost control (Olson \& Zoubi, 2011). To not compromise cost efficiency, performance metrics and compensation systems for managers in the industry should give sufficient consideration to cost control. This research contributes to literature on banking industry efficiency. Aside from complementing existing understanding of the industry's efficiency, it extends our knowledge of factors that influence cost efficiency in the context of Canada. Unlike prior studies, this study is more relevant to the current operating environment of banks in Canada. This study can guide bank management in setting appropriate cost efficiency targets during strategy formulation. In addition, policy makers and regulators can use it as empirical evidence when developing policies and regulatory frameworks aimed at increasing the resilience of the industry, and contribution to the Canadian economy. To understand how the Canadian banking industry compares with banking industry in other countries, future research should consider cross-country analysis. As a measure of performance, enhanced cost efficiency may indicate good performance by managers. However, managers may commit inadequate resources to underwriting and monitoring of loans, realizing cost benefits in the short run but endangering it in the long run (Ding \& Sickles, 2018). In view of this, future research should examine behavioural factors that influence managers' cost efficiency decisions. 


\section{References}

Aboagye, A. Q. (2012). Bank concentration and economic costs of deposit mobilization and credit extension in Ghana. The Journal of Developing Areas, 46(2), 351-370.

Ab-Rahim, R., Md-Nor, N. G., Ramlee, S., \& Ubaidillah, N. Z. (2012). Determinants of cost efficiency in Malaysian banking. International Journal of Business and Society, 13(3), 355-374.

Aiello, F., \& Bonanno, G. (2013). Profits and cost efficiency in the Italian banking industry (2006-2011). Economics and Business Letter, 2(4), 190-205.

Aiello, F., \& Bonanno, G. (2016). Looking at the determinants of efficiency in banking: Evidence from Italian mutual-cooperatives. International Journal of Applied Economics, 30(4), 507-526. https://doi.org/10.1080/02692171.2015.1122747

Akeem, U. O., \& Moses, F. (2014). An empirical analysis of allocative efficiency of Nigerian commercial banks: A DEA approach. International Journal of Economics and Financial Issues, 4(3), 465-475.

Allen, J., \& Engert, W. (2007). Efficiency and competition in Canadian banking. Bank of Canada Review, $\begin{array}{llllll}\text { Summer 2007. } & \text { Retrieved } & \text { on } & \text { November } & \text { from }\end{array}$ https://www.bankofcanada.ca/wp-content/uploads/2010/06/allen-engert.pdf

Allen, J., \& Engert, W., \& Liu, Y. (2007). A Comparison of Canadian and US universal banks: Efficiency, productivity, and the role of technology. Money Affairs, Centro de Estudios Monetarios Latino americanos, CEMLA, XX(1), 61-96. Retrieved on November 3, $2019 . \quad$ from https://www.cemla.org/PDF/moneyaffairs/pub_monaff_xx_01.pdf

Allen, J., \& Liu, Y. (2007). Efficiency and economies of scale of large Canadian banks. Canadian Journal of Economics, 40(1), 225-244.

Amin, S., I., M., Ali, M., H., \& Nor, S. M. (2018). Cost efficiency and liquidity risk in banking: New evidence from OIC countries. International Journal of Business and Management Science, 8(2), 255-276.

Asmild, M., Paradi, J.C., Aggarwall, V., \& Schaffnit, C. (2004). Combining DEA window analysis with Malmquist Index approach in a study of the Canadian banking industry. Journal of Productivity Analysis, 21(1), 67-89.

Balasubramanyan, L., Stefanou, S. E., \& Stokes, J. (2010). Declining cost efficiency as a signal of increasing vulnerability: An entropy-based approach. Applied Economics, 17(18), 1769-1781. https://doi.org/10.1080/13504850903357368

Banerjee, B. (2013). Banking sector efficiency in new EU member states: A survey of cross-country evidence. Eastern European Economics, 50(6), 81-115. https://doi.org/10.2753/EEE0012-8775500604

Bank of Canada (BOC) (2019). Financial system review - 2019. Retrieved on November 8, 2019 from https:/www.bankofcanada.ca/wp-content/uploads/2019/05/Financial-System-Review\%E2\%80\%942019-Ba nk-of-Canada.pdf

Banker, R. D., Chang, H., \& Lee, S. (2010). Different impact of Korean banking system reform on bank productivity. Journal of Banking and Finance, 34(7), 1450-1460. https://doi.org/10.1016/j.jbankfin.2010.02.023

Banker, R. D., Charnes, A., Cooper, W. W. (1984). Some models for estimating technical and scale inefficiencies in Data Envelopment Analysis. Management Science, 30(9), 1078-1092

Banker, R. D., Cooper, W. W., Seiford, L. M., Thrall, R. M., \& Zhu, J. (2004). Return to scale in different DEA models. European Journal of Operational Research, 154, 345-362.

Banya, R., \& Biekpe, N. (2018). Banking efficiency and its determinants in selected frontier African markets. Economic Change and Restructuring, 51(1), 69-95. https://doi.org/10.1007/s10644-016-9200-3

Batir, T. E., Volkman, D. A., \& Gungor, B. (2017). Determinants of bank efficiency in Turkey: Participation banks versus conventional banks. Borsa Istanbul Review, 17(2), 86-96. http://dx.doi.org/10.1016/j.bir.2017.02.003

Belas, J., Kocisova, K., \& Gavurova, B. (2019). Determinants of cost efficiency: Evidence from banking sectors in EU countries. Acta Polytechnica Hungarica, 16(5), 101-123.

Berger, A. N., Hunter, W. C., \& Trimme, S. G. (1993). The efficiency of financial institutions: A review and preview of research, past, present, and future. Journal of Banking and Finance, 17(2-3), 221-249. 
https://doi.org/10.1016/0378-4266(93)90030-H

Berger, A., \& Hannan, T. (1998). The efficiency cost of market power in the banking industry: A test of the "quiet life" and related hypotheses. The Review of Economics and Statistics, 80(3), 454-465.

Berger, A.N., \& Humphrey, D. B. (1997). Efficiency of financial institutions: International survey and directions for future research. European Journal of Operational Research, 98(2), 175-212.

Bucevska, V., \& Misheva, B. H. (2017). The determinants of profitability in the banking industry: Empirical research on selected Balkan countries. Eastern European Economics, 55(2), 146-167. https://doi.org/10.1080/00128775.2016.1260473

Canadian Bankers Association (2019). Focus: Facts about the Canadian banking system. Retrieved on October 29, 2019 from https://cba.ca/Assets/CBA/Documents/Files/Article\%20Category/PDF/bkg_fastfacts_en.pdf

Casu, B., \& Giradone, C. (2006). Bank competition and efficiencies in the single European market. The Manchester School, 74(4), 441-468. https://doi.org/10.1111/j.1467-9957.2006.00503.x

Chan, G. S., Zaini, M., Karim, A. (2016). Financial market regulation, country governance, and bank efficiency: Evidence from East Asian countries. Contemporary Economics, 10(1), 39-54.

Charnes, A., Cooper, W. W., \& Rhodes, E. (1978). Measuring the efficiency of decision-making units. European Journal of Operational Research, 2(6), 429-44.

Coelli, T.J., Rao, D.D.P., O'Donnell, C.J., \& Battese, G.E. (2005). An introduction to efficiency and productivity Analysis (2nd ed.). New York, USA: Springer.

Cooper, W. W., Seiford, L. M., \& Tone, K. (2007). Data envelopment analysis: A comprehensive text with models, applications, references and DEA-solver software (2nd ed.). New York, USA: Springer

Cooray, A. (2009). The financial sector and economic growth. The Economic Record, 85(S1), S10-S21. https://doi.org/10.1111/j.1475-4932.2009.00584.x

Cummings, J. R., \& Durrani, K. J. (2016). Effect of the Basel Accord capital requirements on the loan-loss provisioning practices of Australian banks. Journal of Banking \& Finance, 67, 23-36. https://doi.org/10.1016/j.jbankfin.2016.02.009

Daley, J., Matthews, K., \& Zhang, T. (2013). Post crisis cost efficiency of Jamaican banks. Applied Financial Economics, 23(20), 1599-1607. https://dx.doi.org/10.1080/09603107.2013.839861

Daude, C., \& Pascal, J. (2017). Efficiency and contestability in emerging market banking systems. OECD Journal: Economic Studies, (1), 151-182.

Department of Finance Canada (2016). Supporting a strong and growing economy: Positioning Canada's financial sector for the future: A consultation document for the review of the Federal financial sector framework. Ottawa, Ontario: Department of Finance Canada. Retrieved on October 4, 2019 from https://www.fin.gc.ca/activty/consult/ssge-sefc-eng.pdf

Ding, D., \& Sickles, R. C. (2018). Frontier efficiency, capital structure, and portfolio risk: An empirical analysis of U.S. banks. BRQ Business Research Quarterly, 21(4), 262-277. https://doi.org/10.1016/j.brq.2018.09.002

Feng, G., \& Serletis, A. (2009). Efficiency and productivity of the US banking industry, 1998-2005: Evidence from the Fourier cost function satisfying global regularity conditions. Journal of Applied Econometrics, 24(1), 105-138. https://doi.org/10.1002/jae.1021

Financial Consumer Agency of Canada (FCAC). (2016). Financial Consumer Agency of Canada: 2016-2017 business plan. Cat. No. FC2-4E-PDF. Financial Consumer Agency of Canada. Retrieved on November 8, 2019

from https://www.canada.ca/content/dam/canada/financial-consumer-agency/migration/eng/about/planning/ocum ents/businessplan2016-17.pdf

Fiordelisi, F., Marques-Ibanez, D., \& Molyneux, P. (2010). Efficiency and risk in European banking. Working Paper Series No 1211/June 2010. Germany: Macroprudential Research Network, European Central Bank. Retrieved on October 25, 2019 from https://www.ecb.europa.eu/pub/pdf/scpwps/ecbwp1211.pdf

Forgione, P., Mirza, A., Ammerman, D., \& Armstrong, T. (2017). Getting the deal through: Banking regulation 2017. London, UK: Law and Business Research Ltd. Retrieved on November 8, 2019 from https://www.mcmillan.ca/webfiles/Canadian-Banking-Regulation-2017.pdf

Ghaeli, M. R. (2019). Measuring the relative efficiency of Canadian versus US banks. Accounting, 5(3), 121-126. 
https://doi.org/10.5267/j.ac.2018.9.001

Gunes, H., \& Yildirim, D. (2016). Estimating cost efficiency of Turkish commercial banks under unobserved heterogeneity with stochastic frontier models. Central Bank Review, 16(4), 127-136. https://dx.doi.org/10.1016/j.cbrev.2016.12.001

Gunes, N., \& Yilmaz, A. (2016). Determinants of the efficiencies in Turkish banking sector. International Journal of Economics and Finance, 8(2), 215-225. http://dx.doi.org/10.5539/ijef.v8n2p215

Hartman, T. E., Storbeck, J. E., \& Byrnes, P. (2001). Allocative efficiency in branch banking. European Journal of Operational Research, 134(2), 232-242. https://doi.org/10.1016/S0377-2217(00)00257-5

Hassan, H. I., \& Jreisat, A. (2016). Cost efficiency of the Egyptian banking sector: A panel data analysis. International Journal of Economics and Financial Issues, 6(3), 861-871.

Hoff, A. (2007). Second stage DEA: Comparison of approaches for modeling the DEA scores. European Journal of Operational Research, 181(1), 425-435.

Horvatova, E. (2018). Technical efficiency of banks in Central and Eastern Europe. International Journal of Financial Studies, 6(66), 1-25. https://doi.org/10.3390/ijfs6030066

Howland, M., \& Rowse, J. (2006). Measuring bank branch efficiency using data envelopment analysis: Managerial and implementation issues. INFOR: Information Systems and Operational Research, 44(1), 49-63. https://doi.org/10.1080/03155986.2006.11732739

IBISWorld (2019). Commercial banking in Canada. IBISWorld Industry Report 52211CA. Retrieved on November 8, 2019 from https://clients1.ibisworld.ca/reports/ca/industry/default.aspx?entid=1288

Isik, I., \& Hassan, M. K. (2002). Technical, scale and allocative efficiencies of Turkish banking industry. Journal of Banking \& Finance, 26(4), 719-766.

Kalluru, S. R., Bhat, S. K. (2009). Determinants of cost efficiency of commercial banks in India. The Idai University Journal of Bank Management, 8(2), 32-50

Kamau, A. W. (2011). Intermediation efficiency and productivity of the banking sector in Kenya. Interdisciplinary Journal of Research in Business, 1(9), 12-26.

Kasman, A., \& Carvallo, O. (2013). Efficiency and risk in Latin American banking: Explaining resilience. Emerging Markets Finance \& Trade, 49(2), 105-130. https://doi.org/10.2753/REE1540-496X490207

Klaassen, P., \& van Eeghen, I. (2015). Analyzing bank performance - linking RoE, RoA and RAROC: U.S. commercial banks 1992-2014. The Journal of Financial Perspectives, 3(2), 1-26.

Kocisova, K. (2014). Application of data envelopment analysis to measure cost, revenue and profit efficiency. Statistika, 94(3), 47-57

Kosedag, A., Denizel, M., \& Ozdemir, O. (2011). Testing for convergence in bank efficiency: A cross-country analysis. The Service Industries Journal, 31(9), 1533-47.

Kumar, S. (2013). Banking reform and the evolution of cost efficiency in Indian public sector banks. Economic Change and Restructuring, 46(2), 143-182. https://doi.org/10.1007/s10644-012-9121-8

Kumar, S., \& Gulati, R. (2008). An examination of technical, pure technical, and scale efficiencies in Indian public sector banks using Data Envelopment Analysis. Eurasian Journal of Business Economics, 1(2), 33-69.

Kumbirai, M., \& Webb, R. (2010). A financial ratio analysis of commercial bank performance in South Africa. African Review of Economics and Finance, 2(1), 30-53

Lall, P. (2014). Factors affecting U.S. banking performance: Evidence from the 2007-2013 financial crisis. International Journal of Economics, Finance and Management, 3(6), 282-295.

Lee, T., \& Chih, S. (2013). Does financial regulation affect the profit efficiency and risks of banks? Evidence from China's commercial banks. North American Journal of Economics and Finance, 26, 705-724. https://doi.org/10.1016/j.najef.2013.05.005

Lin, P. W. (2005). An empirical analysis of bank mergers and cost efficiency in Taiwan. Small Business Economics, 25(2), 197-206. https://doi.org/10.1007/s11187-003-6451-y

Maredza, A. (2014). Internal determinants of bank profitability in South Africa: Does bank efficiency matter? International Business \& Economics Research Journal, 13(5), 1033-1046. 
Margaritis, D., \& Psillaki, M. (2007). Capital structure and firm efficiency. Journal of Business Finance \& Accounting, 34(9-10), 1447-1469. https://doi.org/10.1111/j.1468-5957.2007.02056.x

Moradi-Motlagh, A., \& Saleh, A. S. (2014). Re-examining the technical efficiency of Australian banks: A bootstrap DEA approach. Australian Economic Papers, 53(2), 112-128. https://doi.org/10.1111/1467-8454.12024

Moradi-Motlagh, A., Valadkhani, A., \& Saleh, A. S. (2015). Rising efficiency and cost saving in Australian banks: A bootstrap approach. Applied Economics Letter, 22(3), 189-194. https://doi.org/10.1080/13504851.2014.932044

Mousa, G. A. (2015). Financial ratios versus data envelopment analysis: The efficiency assessment of banking sector in Bahrain Bourse. International Journal of Business and Statistical Analysis, 2(2), 75-85. http://dx.doi.org/10.12785/IJBSA/020202

Olson, D., \& Zoubi, T. A. (2011). Efficiency and bank profitability in MENA countries. Emerging Markets Review, 12(2), 94-110. https://doi.org/10.1016/j.ememar.2011.02.003

Ouenniche, J., \& Carrales, S. (2018). Assessing efficiency profiles of UK commercial banks: A DEA analysis with regression-based feedback. Annals of Operations Research, 266(1-2), 551-587. https://doi.org/10.1007/s10479-018-2797-z

Paradi, J., Min, E., \& Yang, X. (2015). Evaluating Canadian bank branch operational efficiency from staff allocation: A DEA approach. Management and Organizational Studies, 2(1), 52-65.http://dx.doi.org/10.5430/mos.v2n1p52

Parsons, S., Gotlieb, C. C., \& Denny, M. (1993). Productivity and computers in Canadian Banking. The Journal of Productivity Analysis, 4(1-2), 95-113. https://doi.org/10.1007/BF01073468

Perera, S., Skully, M., \& Wickramanayake, J. (2007). Cost efficiency in South Asian Banking: The impact of bank size, state ownership and stock exchange listings. International Review of Finance, 7(1-2), 35-60. https://doi.org/10.1111/j.1468-2443.2007.00067.x

Rahman, M. M., Ashraf, B. N., Zheng, C., \& Begum, M. (2017). Impact of cost efficiency on bank capital and the cost of financial intermediation: Evidence from BRICS countries. International Journal of Financial Studies, 5(4), 32. https://doi.org/10.3390/ijfs5040032

Rekik, M., \& Kalai, M. (2018). Determinants of banks' profitability and efficiency: Empirical evidence from a sample of Banking systems. Journal of Banking and Financial Economics, 1(9), 5-23.

Rosman, R., Wahab, N. A., Zainol, Z. (2014). Efficiency of Islamic banks during the financial crisis: An analysis of Middle Eastern and Asian countries. Pacific-Basin Finance Journal, 28, 76-90. https://doi.org/10.1016/j.pacfin.2013.11.001

Rouissi, R. B., \& Bouzgarrou, H. (2012). Cost efficiency of French commercial banks: Domestic versus foreign banks. The International Journal of Business and Finance Research, 6(4), 101-112.

Ruinan, L. (2019). Comparison of bank efficiencies between the US and Canada: Evidence based on SFA and DEA. Journal of Competitiveness, 11(2), 113-129. http://dx.doi.org/10.2139/ssrn.3317196

Saha, A., Ahmad, N. H., \& Dash, U. (2015). Drivers of technical efficiency in Malaysian banking: A new empirical insight. Asian Pacific Economic Literature, 29(1), 161-173. https://doi.org/10.1111/apel.12091

Samad, A. (2014). Noninterest expenses, early warning and bank failures: Evidences from US failed and non-failed Banks. Journal of Accounting and Finance, 14(4), 129-134.

Serebrisky, T. (2012). Airport economics in Latin America and the Caribbean: Benchmarking regulation, and pricing. Washington, DC.: The World Bank

Sharma, D., Sharma, A. K., \& Barua, M. K. (2013). Efficiency and productivity of banking sector: A critical analysis of literature and design of conceptual model. Qualitative Research in Financial Markets, 5(2), 195-224. https://doi.org/10.1108/QRFM-10-2011-0025

Skala, D. (2015). Saving on a rainy day? Income smoothing and procyclicality of loan-loss provisions in Central European Banks. International Finance, 18(1), 25-46. https://doi.org/10.1111/1468-2362.12058

Spulbăr, C., \& Niţoi, M. (2014). Determinants of bank cost efficiency in transition economies: Evidence from Latin America, Central and Eastern Europe and South-East Asia. Applied Economics, 46(16), 1940-1952. https://dx.doi.org/10.1080/00036846.2014.889806 
Spulbar, C., Nitoi, M., \& Anghel, L. (2015). Efficiency in cooperative banks and savings banks: A stochastic frontier approach. Romanian Journal of Economic Forecasting, 18(1), 5-21.

Staněk, R. (2015). Determinants of Bank Efficiency: Evidence from Czech Banking Sector. Acta Universitatis Agriculturae et Silviculturae Mendelianae Brunensis, 63(3), 1005-1011. http://dx.doi.org/10.11118/acta201563031005

Stiroh, K. J., \& Rumble, A. (2006). The dark side of diversification: The case of US financial holding companies. Journal of Banking \& Finance, 30(8), 2131-2161. https://doi.org/10.1016/j.jbankfin.2005.04.030

Tripe, D. (2003). Trends in New Zealand Bank efficiency over time. Applied Econometrics and International Development, 3(1), 55-80. https://EconPapers.repec.org/RePEc:eaa:aeinde:v:3:y:2003:i:3_3

$\mathrm{Vu}, \mathrm{H} .$, \& Turnell, S. (2011). Cost and profit efficiencies of Australian banks and the impact of the global financial crisis. Economic Record, 87(279), 525-536. https://doi.org/10.1111/j.1475-4932.2011.00760.x

Weill, L. (2004). Measuring cost efficiency in European banking: A comparison of frontier techniques. Journal of Productivity Analysis, 21(2), 133-152.

Xiang, D., Shamsuddin, A., \& Worthinton, A.C. (2015). The differing efficiency experiences of banks leading up to the global financial crisis: A comparative empirical analysis from Australia, Canada, and the UK. Journal of Economics and Finance, 39(2), 327-346. https://doi.org/10.1007/s12197-013-9258-y

\section{Copyrights}

Copyright for this article is retained by the author(s), with first publication rights granted to the journal.

This is an open-access article distributed under the terms and conditions of the Creative Commons Attribution license (http://creativecommons.org/licenses/by/4.0/). 